\title{
Research Ethics in the Era of Personalized Medicine: Updating Science's Contract with Society
}

\author{
Eric M. Meslin a Mildred K. Cho ${ }^{\text {b }}$ \\ andiana University Center for Bioethics, IU School of Medicine, Indianapolis, Ind., and ${ }^{b}$ Department of Pediatrics, \\ Stanford Center for Biomedical Ethics, Stanford University, Palo Alto, Calif., USA
}

\section{Key Words}

Personalized medicine $\cdot$ Research ethics

\begin{abstract}
With the completed sequence of the human genome has come the prospect of substantially improving the quality of life for millions through personalized medicine approaches. Still, any advances in this direction require research involving human subjects. For decades science and ethics have enjoyed an allegiance reflected in a common set of ethical principles and procedures guiding the conduct of research with human subjects. Some of these principles emphasize avoiding harm over maximizing benefit. In this paper we revisit the priority given to these ethical principles - particularly the principles that support a cautious approach to science - and propose a reframing of the 'social contract' between science and society that emphasizes reciprocity and meeting public needs.

Copyright $\odot 2010$ S. Karger AG, Basel
\end{abstract}

\section{Introduction}

It is now a familiar refrain that completing the sequence of the human genome will propel science and medicine into new territory, where the prospect of a vastly improved capacity to diagnose and treat disease will substantially improve the quality of life for millions (if not billions) of people. There is a certain amount of concern that these claims may involve a worrisome hype [1-4] since some of the hoped-for benefits have not materialized 10 years after the first 'draft' genome sequence was obtained $[5,6]$. Hype or not, the promise of personalized medicine will only be achieved if science can develop high-quality tests that better identify the risk of disease onset, and then follow this up with effective screening technologies, an expansive medicine cabinet stocked with drugs that can be prescribed with the assurance that they will help (and not hurt) the patients who take them, and appropriate behavioral and public health policies.

Whether this new paradigm is called 'tailored therapeutics', 'personalized medicine' or 'evidence-based medicine', critical to every one is the need to conduct high-quality research involving human subjects. For decades, science and society have been joined by an infor- 
mal, unstated 'social contract' - where society permits (and provides support for) the scientific community to undertake important research, and the scientific community agrees to conduct meritorious studies that will contribute knowledge or other benefit. The contract has not been maintained without difficulty. For example, while there has been an agreement that a common set of ethical principles and procedures guiding the conduct of research with human subjects should be followed, society has witnessed cases of unethical research.

Some of these principles (for example, the principle of nonmaleficence and the principle of precaution) place emphasis on prioritizing avoiding harm or not harming, whereas others (for example, the principles of respect for persons, respect for autonomy and the principle of free inquiry) prioritize freedom, autonomous decision making and personal liberty. While great pains have been made to emphasize that these principles are prima facie binding, without one being more important than the other [7], a certain presumption remains that in research involving human subjects, emphasis is rightly placed on reducing risk and minimizing harm - a protectionist point of view $[8,9]$.

In this paper, we revisit these principles as a way to rethink and reframe the larger 'social contract' between science and society to accommodate advances in genome science. In this way, our proposal is an alternative to the current framework for thinking about research ethics. While the current framework, based on protectionism and the precautionary principle, was necessary to provide the public with an assurance that harm to human subjects would be minimized as science was pursued, the prospect that findings from genomic research will soon bear fruit in clinical practice calls for a new framework - one that still demonstrates a commitment to avoiding harm, but which better enables society to reap the benefits from personalized medicine. Our reframing of science's contract with society will be described as a 'recipe for reciprocity', which calls for scientists to provide society with: (1) a clear articulation of goals and visions of what constitutes benefit, without overstatement of benefit, (2) a commitment to achieving these goals over the pursuit of individual interests, (3) greater transparency, and (4) involvement of the public in the scientific process. In return, society would provide: (1) trust in the process and goals of science, (2) a greater willingness to volunteer to participate in research, (3) sustained, reliable funding, and (4) support for greater academic freedom, free from manipulation by political goals or ideology.

Research Ethics in the Era of Personalized Medicine
We are aware that similar points have been made by others in different contexts, including the 'triple contract' by Veatch [10], or the argument of the National Bioethics Advisory Commission for reciprocity as a principle that binds partnerships in international clinical research [11, 12]. Our intention in recasting the idea of a social contract as involving reciprocal obligations by science and society is to provide a reasoned defense for gradually moving away from a protectionist stance towards a benefit-maximizing one. While our approach is intended to address research in general, we are particularly interested in focusing on the translation of genome research from bench to bedside.

\section{Precaution, Protection and the Pace of Progress}

More than 4 decades ago, the philosopher Hans Jonas defended a protectionist ethical stance as applied to the pace of scientific progress when he wrote:

Let us not forget that progress is an optional goal, not an unconditional commitment, and that its tempo in particular, compulsive as it may become, has nothing sacred about it. Let us also remember that a slower progress in the conquest of disease would not threaten society, grievous as it is to those who have yet to deplore that their particular disease be not yet conquered, but that society would indeed be threatened by the erosion of those moral values whose loss, possibly caused by too ruthless a pursuit of scientific progress, would make its most dazzling triumphs not worth having. [13]

Jonas' caution was understandable, given both his personal appreciation of the horrific experiments in the concentration camps, the current state of federal regulation of human subjects in the US at that time (the first federal regulation was still years in the future) and his thoughtful reflections on science generally. Jonas' argument, and indeed much of his abiding philosophy, serves as a powerful reminder that science is a privilege, not a right.

A decade later, Stephen Stich provided a more straightforward description of the principle of precaution - which he described as one of 'three bad arguments' that had been advanced in the early recombinant DNA debates:

We are, after all, dealing with a relatively new an unexplored technology ... Indeed, it is not impossible that we could find ourselves confronted with a killer strain of, say, E. coli and worse, a strain against which humans can marshal no natural defense. Now, if this is possible - if we cannot say with assurance that the probability of it happening is zero - then, the argument continues, all recombinant DNA research should be halted. [14]

Public Health Genomics 2010;13:378-384 
Stich expertly attacked the strong version of this principle of precaution, at one point calling it 'sophistry' because of the error of 'going from the undeniable premise that recombinant DNA research might possibly result in unthinkable catastrophe to the conclusion that such research should be banned' without also articulating a moral premise that all cases of the former ought to be banned.

Though not often linked as we have done here, the Jonas and Stich positions are part of the history that helped shape much of the US regulatory landscape for the past 30 years. Indeed, Moreno [9] has recently argued that an apt description of the ethical foundation of the US oversight system for human subjects research (domestic and international) is best understood as a type of protectionism which he describes as 'the view that a duty is owed those who participate as subjects in medical research'. The current system is one of 'moderate protectionism', neither weak nor strong:

Weak protectionism is the view that this problem is best resolved through the judgment of virtuous scientists ... Strong protectionism is disinclined to rely on the virtue of scientific investigators for purposes of subject protection to any substantial degree. [9]

Moderate protectionism by contrast may be understood as an application of several of the traditional bioethics principles articulated by Beauchamp and Childress [7], but with an emphasis on prioritizing nonmaleficence to a greater extent than beneficence, respect for persons or justice. The evidence of this type of protectionism is found in many places: beginning with the very name of the office originally established to oversee implementation of federal regulations - the Office for Protection from Research Risks (OPRR, now OHRP) [15] - and can also be seen in the form of increased scrutiny by regulators, more regulation and requirements of scientists, added layers of requests for conflict of interest disclosures, and requirements for 'broader impact' statements [16] in research grant applications.

If this type of protectionism is occurring, it may reflect a decrease in trust in scientists and the institutions in which they work, such as universities [17]. But it may also be evidence of the fickle relationship between science and society - where the latter's support of the former waxes and wanes. Support may come easily when discoveries lead to treatments but can just as easily disappear when the scientific community is perceived as being part of a conspiracy [18] or influenced by industry and financial incentives [19]. The recent case involving the Havasupi
Tribe and Arizona State University [20] suggests that even 2-decade-old cases still elicit strong protectionist reactions.

Contrast these examples with efforts to carry out research with (arguably) fewer protections than before. The widespread development of biobanks now elicits intense discussion about whether we are requiring too many or too few protections [21-24]. For example, while the public is willing to participate in biobank research $[25,26]$, they do have reservations $[27,28]$. The Vanderbilt biobank uses an 'opt-out' approach to informed consent [29] which, while increasing the likelihood of increased participation, still challenges the well-accepted norm of informed consent [30]. Common to all perspectives on this issue is the perceived trustworthiness of the scientists conducting this research [31-33].

Thus, what we may be witnessing is a shifting emphasis in the tension between individuals, scientists and society. Whereas the early days of modern research ethics adopted a strong protectionist stance, more recently, we have seen the pendulum swing towards more moderate forms of protectionism [9]. Genomics research would do well to pay attention to this history, where there has always been a notable tension between the interests of participants in research and those who conduct research. The gap between scientists' perception of worthwhile research and non-scientists' perceptions has been filled somewhat through the work of community engagement and patient advocacy groups [34], for example, who have taken the lead in determining research priorities.

\section{Genomic Science, Progress and Beneficence}

Just as genomic science is potentially game changing from the perspective of medicine and science, so too might the resolution of several research ethics challenges likely influence science progress in that domain. For example, while not fully resolved, we are nevertheless learning more about how to improve informed consent and privacy protection from the ongoing conversations about their importance in biobanks [30, 35, 36].

The potential for genomics to actually change medical practice (whether in short or longer terms) creates an ethical imperative for researchers to carefully apply the principles of beneficence and nonmaleficence - on the one hand to encourage research to promote human health, while avoiding unscrupulous use of individuals in research. This is especially important as society becomes more informed about genomics and raises questions 
about the appropriate uses of genetic testing, screening and pharmacogenetics. Similarly, the advent of personal genomics services for 'recreational' purposes [3] and other non-medical uses such as assessment of athletic abilities in children $[37,38]$ provides opportunities for the application of genomic research in numerous new ways that appropriately warrant caution.

It is one thing to go cautiously, to heed Jonas' call for progress as an optional goal and not as an unconditional commitment, but the consequences of taking Jonas seriously - of not doing research - are simply too high. Indeed, the new reality of science policy, Varmus [39] calls it the 'politics of science', now finds the National Institutes of Health and other granting agencies emphasizing impact, return on investment, adding value, de-risking and translating discoveries into practice. This emphasis suggests that while a focus on precaution and harm avoidance is still expected it carries less weight than in the past. Some go so far as to argue that in certain areas of public health research, it would be unethical not to carry out research that advances public health [40]. This is a new approach to research ethics, which we now explicate.

\section{Examples of Successful Contracting}

In thinking about social contracts for biomedical and genome research, we can draw on a long history of theory and practice. Civil society has a long made use of the social contract traditions of 17 th and 18th century political philosophers such as Hobbes, Locke and Rousseau. Modern theorists such as John Rawls, Kai Nielson and David Gauthier proposed ways in which society might rethink its relationship with government and with civil society more generally. And even contemporary science writers have observed that ever since the founding of the country, there was an interest in science as a component of the developing democracy [41].

While no formal contract per se has been prepared, signed or negotiated, there are several examples of implied contracts. The implied social contract proposed for post-war American science by Vannevar Bush [42], and to some extent by John Steelman [43], are noteworthy examples of the following negotiation: in exchange for public support in the form of federal dollars, the scientific community would be granted a high level of intellectual autonomy and self-governance in the conduct of basic science with great deference given to the expertise of the scientist. This support was expected to return technological benefits to the public, but what these benefits were and how they were to be accrued was left largely to the scientific community. This relationship depended on assumptions about the integrity of scientists and the 'easy translation of research results into economic and other benefits' $[43,44]$. Indeed, the recombinant DNA debate referred to above is an instructive example of how the implied contract worked to the mutual benefit of science and society: by imposing a moratorium on their own research following discussions at the Asilomar Conference Center in 1973-74, scientists presented themselves to the public as responsible investigators who could be trusted with dangerous tools; in exchange, they were given the authority and responsibility to undertake valuable research. The use of guidelines by the National Institutes of Health's Recombinant DNA Advisory Committee that have remained substantially untouched since first proposed following Asilomar is evidence of this continued trust [45].

Other examples exist. When President Truman proposed the need for the atomic bomb, or when President Kennedy made his case to go to the Moon, or James Watson requested USD 3 billion from the US Congress and promised to map and sequence the genome in 15 years, science was engaged in an implicit form of contracting with society (via Congress). All 3 contracts were fulfilled. Some have even described Richard Nixon's 1971 'war on cancer' proposal to be a success, even though all cancer has not been conquered. Former National Cancer Institute Director Vincent DeVita, MD, recently observed that:

(The war on cancer) ... did everything it was supposed to do. It supported basic research handsomely. It set up application programs - the EORTC (European Organisation for Research and Treatment of Cancer) and US clinical trials programs. The incidence of cancer in this country started dropping in 1990 and has continued to drop every year since, and so has mortality. And the morbidity from cancer, comparing 1971 to 2005, is like night and day ... So, every benchmark of the mandate has been hit. [46]

Following many years of underfunding national science during the Bush administration, a renewed effort at supporting science is underway by President Obama. His priorities for science, which he has called an 'investment in innovation' make a compelling case for funding science not only because of the promise of new treatments and better health that may result, but because of a direct connection between scientific innovation and economic prosperity [41]. Obama's argument has echoes of Vannevar Bush's claim in Science: The Endless Frontier. 
Advances in science when put to practical use mean more jobs, higher wages, shorter hours, more abundant crops, more leisure for recreation, for study, for learning how to live without the deadening drudgery which has been the burden of the common man for ages past ... Advances in science will also bring higher standards of living, will lead to the prevention or cure of diseases, will promote conservation of our limited national resources, and will assure means of defense against aggression. But to achieve these objectives - to secure a high level of employment, to maintain a position of world leadership - the flow of new scientific knowledge must be both continuous and substantial. [42]

\section{Updating the Social Contract between Science and Society}

More recently, some have argued that despite the few successful contracts described above, the evolution of the environment in which science takes place may now require a revision of the contract. Gibbons [47] suggests that the goals of science should be to create 'socially robust knowledge' that centrally incorporates public needs into research design, in contrast to primarily serving the needs of scientific validity. Guston [44] argues that a simple rearticulation of or rededication to the contract is insufficient because of a breakdown in trust, which has been replaced by oversight. Instead, he proposes a 'collaborative assurance' between government, policy makers, scientists and the public. Guston's proposal is not unlike the 'triple contract' that Veatch proposed for relationships between patients, professionals and society. Veatch [10] argued that in societies that trace their political philosophy to the social contract tradition, there are $2 \mathrm{com}$ peting views about how the principles governing health care relationships may arrived at - one view involves those who discover the principles of morality by appealing to something 'prior to and more basic than the human community' (perhaps a deity); another view is to invent the principles of morality through a process of consensus development. According to Veatch:

There is every reason to believe that people taking these two closely related points of view would agree to a set of principles, would contract or covenant together to acknowledge the basic relationships of the moral community. The result would be a set of basic ethical principles discovered by or generated by a moral community bound together in loyalty and fidelity ... Once people have articulated this basic social covenant, there is also reason to believe that they would continue in the covenant mode drawing up a second covenant. [10, pp. 325-326]

Veatch's view resonates to a great extent with the idea that science is a public good and that the terms of how this good is to be developed, shared, protected, maintained, and cultivated might best be decided by agreement between all those who participate in this activity: patients and their physicians, researchers and participant, sponsors and researchers, regulators and Congress.

\section{Recipe for Reciprocity}

We propose a reframing of the social contract in science through the lens of reciprocity, which carries with it a sense of mutual dependence, respect and justice, not only for those within one's own group but for all others. For scientists, this implies a professional obligation that is somewhat weaker than the traditional sense of the fiduciary, which requires that personal interests be set aside on behalf of the beneficiary. On the other hand, this obligation is stronger than a duty of care, which emphasizes nonmaleficence. In addition, it must emphasize the needs of the public as beneficiaries, because unlike other professions, biomedical research is heavily reliant on direct public support.

However, retreating from a strong protectionist stance requires the scientific community to step forward into a stronger role that provides reassurance to the public that their end of the bargain is being met by (1) assuring that the goals of research projects are primarily to meet public needs, rather than self-interest, and (2) acknowledging that the specialized knowledge of the scientific community creates a moral hazard (from the imbalance of knowledge) between the public or government funders and the experts, and thus, an obligation to demonstrate trustworthiness [44]. This requires some articulation of whether science is a profession that holds itself to a service ideal, as medicine or law, and if so, as Chadwick [48] asked, who is served?

Therefore, the 'recipe for reciprocity' we are proposing calls for commitments from both science and society. The scientific community would provide: (1) an articulation of goals and visions of what constitutes benefit, without overstatement of benefit, (2) a commitment to achieving these goals over pursuit of individual interests, (3) greater transparency, and (4) involvement of the public in the scientific process, with the goal of increasing trust in this process. In return, society would provide: (1) participation in research, (2) sustained, reliable funding, and (3) academic freedom, free from manipulation by political goals. Preparing the recipe is one thing, constructing and negotiating it is another thing. Below, we offer some final reflections on how (and by whom) this process would occur. 


\section{Next Steps: Constructing and Negotiating the Science Social Contract for Genomics}

Key to the idea of implementing this reframed social contract is the education of the parties on both sides of the contract. In strengthening the commitment to public benefit, beginning with the determination of what constitutes a benefit from the perspective of a variety of stakeholders, scientists educate themselves about the needs and goals of others outside the scientific community. These stakeholders include not just the general public or patient advocates, but clinicians who are most likely to incorporate genomics into their practices, payers of health services, biotechnology and pharmaceutical industry members, research professional societies, research funders, and others. A variety of stakeholder views about their visions of benefit and potential harms and barriers should be solicited by the scientific community. Public needs can also be incorporated by including lay participants in the selection of research questions, design or peer review of findings [49], or through benefit-sharing governance models [50].

To the extent that genome research is seen as benefiting science [6] (more than medicine), it is important for scientists to visibly and transparently articulate their commitment to achieving public benefit over what could be perceived as self-serving goals of conducting research because it is interesting, advances careers or enhances financial enrichment. Financial and other conflicts of interest should be minimized and clearly justified if they cannot be avoided.

There is also the need for an educated public. However, challenges confront such an approach. Were it simply a matter of emphasizing more and better science education in schools, we would still be confronted with dwindling school budgets, poorly compensated teachers and pockets of anti-science ideology on school boards and in state legislatures [51-53]. Were it simply a matter of entrusting the contracting to elected members of state or the federal public office, it would be difficult for scientists to inform policy $[54,55]$.

On the other hand, there is hope for some optimism for a renewal of science literacy in the Obama administration, beginning with his inauguration speech in which he said: 'We will restore science to its rightful place, and wield technology's wonders to raise health care's quality and lower its cost.' A case example of the pitfalls in the translation of genome-wide association studies to human health illustrates what integration of societal goals might look like for genomics that involves all stakeholders in the translational pathway. While some have characterized these studies to have 'limited success' at leading to treatments, such as drugs targeted against specific genetic conditions or finding connections between genetic variants and common diseases [5], we suggest that part of the reason for this limited success is because the tools used, such as single nucleotide polymorphism chips, were primarily designed to address broad basic scientific questions as opposed to solving specific clinical problems. As a result, very few single nucleotide polymorphisms on commercially available chips correspond to common human diseases for which Clinical Laboratory Improvement Amendments-approved genetic tests are offered by clinical labs [56]. Closing this translational gap may require a conscious shift towards designing tools and studies specifically for this purpose, by chip designers taking into account what types of findings clinicians or patients would find useful and how genomic findings would be actually used in practice. Thus, integration of societal goals into genomic research through the interaction of a wide variety of stakeholders could facilitate translation of genomic research.

\section{Acknowledgments}

E.M.M. is supported by the IU Center for Bioethics program in Predictive Health Ethics Research (PredictER) which is supported by a grant from the Richard M. Fairbanks Foundation, Indianapolis; Grant No. UL1RR025761-01, NCRR/NIH: Indiana Clinical and Translational Sciences Institute; Institute for Advanced Studies, Professor at Large Program, University of Western Australia. M.K.C. is supported by the National Human Genome Research Institute grant No. P50 HG003389 and NIH grant U54 RR024374-01A1.

References

$\checkmark 1$ Caulfield T: Underwhelmed: hyperbole, regulatory policy, and the genetic revolution. McGill Law J 2000;45:437.

2 Caulfield T: Popular media, biotechnology, and the cycle of hype. J Health Law Policy 2005;5:213.

-3 Evans JP: Recreational genomics; what's in it for you? Genet Med 2008;10:709-710.

4 Evans J, Green R: Direct to consumer genetic testing: avoiding a culture war. Genet Med 2009; 11:568.

$>5$ The human genome at ten. Nature 2010;464 649-650.

6 Wade N: A decade later, genetic map yields few new cures. New York Times, June 12, 2010, http://www.nytimes.com/2010/06/13/ health/research/13genome.html. 
7 Beauchamp TL, Childress JF: Principles of Biomedical Ethics, ed 6. New York, Oxford University Press, 2008.

8 Moreno J, Caplan AL, Wolpe PR: Updating protections for human subjects involved in research. Project on Informed Consent, $\mathrm{Hu}$ man Research Ethics Group. JAMA 1998 280:1951-1958.

9 Moreno JD: Protectionism in research involving human subjects; in National Bioethics Advisory Commission (ed): Commissioned Papers and Staff Analysis. Bethesda, NBAC, 2001, vol 2, pp I.1-I.21. http://bioethics.georgetown.edu/nbac/human/overvol2. pdf.

10 Veatch RM: Theory of Medical Ethics. New York, Basic Book, 1981.

11 National Bioethics Advisory Commission: Ethical and policy issues in international research. Clinical trials in developing countries; in National Bioethics Advisory Commission (ed): Report and Recommendations of the National Bioethics Advisory Commission. Bethesda, NBAC, 2001, vol 1.

12 Macklin R: Double Standards in Medical Research in Developing Countries. Cambridge, Cambridge University Press, 2004.

13 Jonas H: Philosophical reflections on experimenting with human beings; in Jonas $\mathrm{IH}$ (ed): Philosophical Essays: From Current Creed to Technological Man. Chicago, University of Chicago Press, 1980, pp 105-131.

14 Stich SP: The recombinant DNA debate. Philos Public Aff 1978;7:187-205.

15 McCarthy CR, Meslin EM: The Office for Protection from Research Risks; in Blank RH, Merrick J (eds): Encyclopedia of US Biomedical Policy. Westport, Greenwood Publishing, 1996.

16 National Science Foundation. http://www. nsf.gov/pubs/2007/nsf07046/nsf07046.jsp. 2007.

17 Duderstadt J: Beyond the endless frontier. Science, the endless frontier: a policy evaluation and formulation conference. New York, Columbia University, September 1996, pp 1-12.

18 Mills E, Jadad AR, Ross C, et al: Systematic review of qualitative studies exploring parental beliefs and attitudes toward childhood vaccination identifies common barriers to vaccination. J Clin Epidemiol 2005;58:10811088.

19 Kaiser J: Ethics. Private money, public disclosure. Science 2009;325:28-30.

20 Mello MM, Wolf LE: The Havasupai Indian tribe case - lessons for research involving stored biologic samples. N Engl J Med 2010; 363:204-207.

21 Caulfield T, Kaye J: Broad consent in biobanking: reflections on seemingly insurmountable dilemmas. Med Law Int 2009; 10: 85-100.
22 Clayton EW: Informed consent and biobanks. J Law Med Ethics 2005;33:15-21.

23 Brekke O, Sirnes O: Population biobanks: the ethical gravity of informed consent. Biosocieties 2006;1:385-398.

24 Elger BS, Caplan AL: Consent and anonymization in research involving biobanks: differing terms and norms present serious barriers to an international framework. EMBO Rep 2006;7:661-666.

25 Joseph JW, et al: Empirical data about women's attitudes toward a biobank focused on pregnancy outcomes. Am J Med Genet A 2008; $146: 305-311$.

26 Hoeyer K, et al: Informed consent and biobanks: a population-based study of attitudes towards tissue donation for genetic research. Scand J Public Health 2004;32:224-229.

27 Murphy J, et al: Public perspectives on informed consent for biobanking. Am J Public Health 2009;99:2128-2134.

28 Bates BR, et al: Warranted concerns, warranted outlooks: a focus group study of public understandings of genetic research. Soc Sci Med 2005;60:331-344.

29 Roden DM, et al: Development of a largescale deidentified DNA biobank to enable personalized medicine. Clin Pharmacol Ther 2008;84:362-369.

30 Caulfield T, Brown R, Meslin EM: Challenging a well established consent norm? One time consent for biobank research. JIBL 2007;4:69-74.

-31 Axler RE, et al: Why might people donate tissue for cancer research? Insights from organ/ tissue/blood donation and clinical research. Pathobiology 2008;75:323-329.

32 Meslin E: The value of using top-down and bottom-up approaches for building trust and transparency in biobanking. Public Health Genomics 2010;13:207-214.

33 Hansson MG: Building on relationships of trust in biobank research. J Med Ethics 2005; 31:415-418.

34 Epstein S: Impure Science: AIDS, Activism, and the Politics of Knowledge. Berkeley, University of California Press, 1996, pp 1-466.

35 Caulfield T: Biobanks and blanket consent: the proper place of the public good and public perception rationales. Kings Law J 2007; 18:209-226.

36 Evans BJ: Ethical and privacy issues in pharmacogenomic research; A.C.o.C. Pharmacy (ed): Pharmacogenomics: Applications to Patient Care. Lenexa, American College of Clinical Pharmacy, 2009.

37 Macur J: Born to run? Little ones get test for sports gene. New York Times, November 29 2008, p A1.

38 Atlas Sports Genetics. http://www.atlasgene. com/. 2009.

39 Varmus H: The Art and Politics of Science. New York, WW Norton and Company, 2009.

-40 Stanley F, Meslin E: Australia needs a better system for health care evaluation. Med J Aust 2007; 186:220.
41 Yancy C, Miller ED, Lucier G: Investing in recovery and discovery. Science Progress 2010. http://www.scienceprogress.org/2010/ 02/medical-research/.

42 Bush V: Science: The Endless Frontier. A Report to the President by Vannevar Bush, Director of the Office of Scientific Research and Development. Washington, DC, US Government Printing Office, http://www. nytimes.com/2010/05/21/education/ 21textbooks.html, 1945, pp 1-28.

43 Steelman JR: Science and Public Policy. The President's Scientific Research Board. Washington, US Government Printing Office, 1947, vol 5 .

44 Guston DH: Retiring the social contract for science. Issues Sci Technol 2000;summer: 32-36.

45 Cornetta K, Meslin EM: Ethical and scientific issues in gene therapy and stem cell research; in Chadwick R, Ten Have H, Meslin EM (eds): Health Care Ethics in an Era of Globalization. New York, Sage (in press).

46 Haran C: Vince De Vita: the view from the top. Cancer World 2005;June-July:38-43.

47 Gibbons M: Science's new social contract with society. Nature 1999;402(suppl 6761): C81-C84.

48 Chadwick RR: Professional ethics and the 'good' of science. Interdiscip Sci Rev 2005; 30:247-256.

49 Kitcher P: Responsible biology. Bioscience 2004;54:331-336.

50 Kaye J, Stranger M (eds): Principles and Practice in Biobank Governance. Surrey, Ashgate, 2009.

51 The Associated Press: Texas approves textbook changes. New York Times, May 22. http://www.nytimes.com/2010/05/22/ education/22texas.html.

52 Birnbaum M: Historians speak out against proposed Texas textbook changes. Washington Post, March 8. http://www.washingtonpost.com/wp-dyn/content/article/2010/03/ 17/AR-2010031700560.html.

53 Brick M: Texas school board set to vote textbook revisions. New York Times, May 20. http://www.nytimes.com/2010/05/21/ education/21textbooks.html.

54 Sinks T, Wagner W, Farquhar D: The science and the law of toxics. J Law Med Ethics 2007;35:63-68

55 Lempinen EW: Vernon Ehlers, congressman and physicist, urges scientists and engineers to join the political process. http://www. aaas.org/news/releases/2010/0602stpf ehlers.shtml. 2010

56 Johnson $\mathrm{AD}$, et al: Notifiable genetic variants on commercially available SNP arrays: implications for research participants in genome-wide association studies for cardiovascular disease. Circulation 2010;120(suppl 559):1-3. 